\title{
КРИМІНАЛІСТИЧНА ХАРАКТЕРИСТИКА ОСОБИ ПРАВОПОРУШНИКА ЧЕРЕЗ ПРИЗМУ КРИМІНАЛЬНИХ ПРАВОПОРУШЕНЬ ЗА ФАКТАМИ ОБІГУ ПОРНОГРАФІЧНИХ ПРЕДМЕТІВ
}

Постановка проблеми. Метою досудового розслідування є розшук та викриття особи, яка вчинила кримінальне правопорушення. Дане питання розглядалось науковцями у кримінально-правовому, кримінологічному та криміналістичному значеннях. Проте вивчення особи правопорушника у межах методики розслідувань кримінальних правопорушень за фактами обігу порнографічних предметів залишається недостатньо дослідженим.

Аналіз останніх досліджень та публікацій. Поняття особи правопорушника розглядалось відомими вченими-криміналістами. Серед них Т.В. Аверьянова, В.П. Бахін, Р.С. Бєлкін, П.Д. Біленчук, А.Ф. Волобуєв, В.А. Журавель, І.І. Когутич, О.Н. Колесніченко, В.О. Коновалова, В.О. Малярова, В.К. Лисиченко, О.В. Одерій, М.В. Салтевський, А.В. Старушкевич, В.В. Тіщенко, Л.Д. Удалова, В.Ю. Шепітько, М.П. Яблоков та інші. В рамках методики розслідування кримінальних правопорушень проти моральності у сфері статевих відносин дане питання розглядалось Г.О. Івановою, Д.Г. Паляничко, М.І. Свєнтіковою, С.В. Хільченком.

Метою даної статті є аналіз результатів наукових досліджень криміналістичної характеристики особи правопорушника, визначення змісту, наукового та практичного значення даного поняття, дослідження особи правопорушника у взаємодії з іншими елементами структури криміналістичної характеристики, узагальнення наукових досліджень щодо особи, яка вчинила кримінальне правопорушення за фактами обігу порнографічних предметів.

Виклад основного матеріалу. Поняття особи правопорушника широко використовують в кримінально-правовому, кримінологічному та криміналістичному значеннях. На думку професорів Т.В. Аверьянової, Р.С. Бєлкіна, Ю.Г. Корухова, О.Р. Россінської вказівки на особу ймовірного злочинця та ймовірну жертву - це дані, які криміналістика черпає з кримінологічної характеристики злочину. Саме кримінологія та віктимологія вивчають особистість злочинця та потерпілого, зв'язок між ними [1, с. 699]. Відповідно до кримінально-правового значення - суб'єкт кримінального правопорушення, передбаченого ст. 301 Кримінального кодексу України - це фізична осудна особа, яка на момент вчинення кримінального правопорушення досягла 16-річного віку. Проте, на відміну від кримінально-правового та кримінологічного значень, в криміналістиці поняття особи правопорушника містить усі ознаки та характеристики особи правопорушника, які можуть бути використані при розслідуванні кримінального правопорушення. На думку М.П. Яблокова, особа злочинця є об'єктом самостійного криміналістичного дослідження, а дані про нього - важливим елементом криміналістичної характеристики кримінального правопорушення [2, с. 70].

(c) М. В. Войчишена, 2019 
А.Ф. Волобуєв зазначає, що «у криміналістиці загальновизнаним $€$, що криміналістичне дослідження особи злочинця слід розуміти як пошук криміналістично значущої інформації про невідомого злочинця та оцінку даних про осіб, котрі потрапили в поле зору кримінального судочинства» [3]. Ми не можемо не погодитись, адже під час досудового розслідування важливою є будь-яка інформація, яка свідчить про особу, що вчинила правопорушення та може вказати на певні риси, які виокремлюють правопорушника з-поміж інших осіб.

Конкретний зміст даного елемента криміналістичної характеристики визначається набором ознак особистості, специфічних для осіб, які вчиняють правопорушення даного виду, та істотних для їх успішного розслідування [4, с. 39]. На основі слідчої та судової практики формуються типові характеристики осіб, які вчиняють певні види кримінальних правопорушень, які надалі використовуються правоохоронцями з метою ефективного розшуку правопорушників. Зазвичай, інформація про особу правопорушника міститься не тільки в показаннях свідків, потерпілих, результатах експертних досліджень, але й в слідах кримінального правопорушення та способі його вчинення. На думку М.В. Салтевського «криміналістична характеристика особи злочинця повинна давати опис людини як соціально-біологічної системи, властивості й ознаки якої відбиваються в матеріальному середовищі та використовуються для розслідування злочинів» [5, с.422].

Не можливо не погодитись з М.П. Яблоковим, який зазначає, що результати кожної злочинної діяльності містять сліди особистості людини, яка її здійснила, i, зокрема, відомості про деякі його особисті соціально-психологічні властивості та якості, злочинний досвід, спеціальні знання, стать, вік, особливості взаємин 3 жертвою кримінального правопорушення [2, с. 70].

Аналізуючи інформацію про особу правопорушника, зауважимо на важливості отримання криміналістично значущої інформації при дослідженні взаємозв'язків елементів криміналістичної характеристики. І.Ф. Герасимов та Л.Я. Драпкін наголошують на тому, що кореляційна залежність існує в зв'язках між способом та особою правопорушника, між місцем та часом вчинення кримінального правопорушення та особистістю правопорушника, між особливостями особистості та поведінки потерпілого та діями правопорушника [6, с. 332]. Так, досліджуючи спосіб, знаряддя та засоби вчинення кримінального правопорушення, предмет злочинного посягання, особу потерпілого, типові сліди кримінального правопорушення, а також обстановку та місце його вчинення можливо отримати вичерпну інформацію, яка характеризує особу правопорушника, та навпаки, досліджуючи ознаки особи правопорушника стає можливим отримати інформацію про те, яким способом правопорушник вчинив протиправне діяння, які знаряддя та засоби використовував. Крім зв'язку «кримінальне правопорушення - потерпілий - правопорушник» можуть бути та інші взаємозалежності, наприклад, «сліди кримінального правопорушення - спосіб вчинення - час вчинення кримінального правопорушення - правопорушник», "місце - обстановка кримінального правопорушення - правопорушник» [4, с. 38]. Такі взаємозалежності між елементами структури криміналістичної характеристики вказують на необхідність їх дослідження у сукупності та взаємодії. 
Здатність слідчих та оперативних співробітників до виявлення та аналізу отриманої на місці події та під час досудового розслідування криміналістичної інформації впливає на подальше досудове розслідування, якість та тактику проведення слідчих (розшукових) дій, побудови криміналістичних версій щодо вчинення кримінального правопорушення та розшуку особи правопорушника. М.П. Яблоков зазначає, що виявлення форм вираження особистості в первинній інформації про подію кримінального правопорушення та в ході розслідування дозволяє скласти уявлення про загальні, а потім й приватні особистісні особливості правопорушників [2, с. 70].

Таким чином, аналіз ознак, рис, властивостей та особливостей особи правопорушника в рамках криміналістичної характеристики дає можливість сформулювати інформаційну модель правопорушника, який вчинив певне протиправне діяння та визначитися з обставинами, що стали причиною протиправної поведінки особи. «Відомості про особу, що вчинила кримінальне правопорушення, як один зі значимих елементів криміналістичної характеристики, є підгрунтям та відправною точкою для визначення інших елементів криміналістичної характеристики, побудови криміналістичних версій, обрання тактичних особливостей проведення окремих слідчих (розшукових) дій тощо» [7, с. 112].

М.В. Салтевський відносить до особи злочинця «фізичні, біологічні та соціальні» властивості [5, с. 422]. Такими властивостями, на нашу думку, можуть бути вік, фізичний та психологічний стан, сфера діяльності, навички та вміння, спосіб життя, сімейний стан, моральні якості, інтереси, коло оточення. Таким чином, ми можемо поділити ознаки та властивості особи правопорушника на такі групи: 1) демографічні ознаки (стать, вік, місце проживання, спосіб життя); 2) сфера діяльності особи (місце роботи або навчання, освіта, професія); 3) навички та спеціальні знання, схильності особи; 4) особистісні ознаки (моральні якості, психологічні особливості, інтереси); 5) взаємодія з потерпілою особою.

На думку І.Ф. Пантелеєва, важливою ознакою є професійні навички злочинців, які знаходять своє відбиття у визначених способах та прийомах вчинення кримінальних правопорушень, залишають на місці правопорушення «почерк» злочинця. Крім того, І.Ф. Пантелеєв зазначає й про такі ознаки особи правопорушника, як жорстокість та невігластво, які, на нашу думку, характеризують психологічні особливості правопорушника [8, с.465, 466].

Криміналістичний аналіз ознак та властивостей особи правопорушника як елемента криміналістичної характеристики має не тільки наукове значення, а й практичне, що знаходить своє вираження в ефективній превентивній діяльності та успішному розслідуванні кримінальних правопорушень. «Саме вивчення соціально-демографічних, психологічних, поведінкових та інших ознак особи, яка вчинила кримінальні правопорушення, сприяє встановленню ознак та якостей, що стали підгрунтям злочинної поведінки. Відповідно, такі відомості сприятимуть ефективності діяльності із запобігання вчиненню кримінальних правопорушень та впливатимуть на якість та швидкість досудового розслідування кримінальних правопорушень» [7, с. 111].

В рамках дослідження особи правопорушника важливо розглянути питання співучасті при вчиненні кримінального правопорушення. В кримінально-правовому 
значенні співучастю є умисна спільна участь декількох суб'єктів кримінального правопорушення у вчиненні умисного кримінального правопорушення [9]. Деякі вчені-криміналісти зазначають, що співучасть у вчиненні кримінальних правопорушень має розглядатися як окремий елемент криміналістичної характеристики, бо його детальне вивчення дасть можливість отримати необхідну інформацію про спосіб вчинення кримінального правопорушення.

І.Ф. Пантелеєв зазначає, що успіх розкриття групових кримінальних правопорушень багато в чому залежить від криміналістичної характеристики співучасті [8, с. 465], а В.В. Тіщенко говорить, що в кримінальних правопорушеннях, які здійснюються групою осіб, повинні міститися дані про типовий її склад, ієрархії, рольових функціях при підготовці, вчиненні, приховуванні кримінального правопорушення, реалізації викраденого та тому подібне. [10, с. 61]. Вивчення та аналіз ролі кожного з учасників групи при вчиненні кримінального правопорушення надасть можливість всебічного розслідування та отримання необхідної доказової бази та інформації про спосіб та механізм вчинення кримінального правопорушення. М.П. Яблоков зауважує, що при вивченні особливості групи з точки зору ступеня iï організованості, структури, розгалуження, рольових функцій її учасників дає можливість краще зорієнтуватися в напрямках розшуку фактичних даних, необхідних для розкриття всіх ланок злочинної діяльності членів групи та всіх основних епізодів їх діяльності [2, с. 71].

Детального дослідження потребує поняття особи правопорушника через призму кримінальних правопорушень за фактами обігу порнографічних предметів. M.I. Свєнтікова говорить, що «вивчення особи виготовлювача, збувальника та розповсюджувача порнографічних предметів є завданням цілої низки слідчих дій, оперативно-розшукових та інших заходів та здійснюється протягом усіх стадій кримінального процесу» [11, с. 157]. Під час досудового розслідування необхідним є встановлення мотиву та цілей такої діяльності, місця та обстановки, способів вчинення протиправних дій, кількість та ролі учасників, а також характеристику кожного з них.

С.В. Хільченко зазначає, що «злочинці, які поширюють порнографічні предмети - це особи раніше не судимі чи судимі за аналогічні злочини, насильницьке мужолозтво, розбещення неповнолітніх, зґвалтування й інші подібні злочини. Оскільки діяльність з виготовлення та реалізації такої продукції вимагає наявності хоча б елементарних знань із відповідної галузі, такі особи часто мають середню чи вищу освіту або ж навчаються» [12, с. 37].

Вивчення особи правопорушника дає можливість побудувати типовий портрет особи, яка займається ввезенням, виготовленням, збутом та розповсюдженням порнографічних предметів до яких можна віднести не тільки демографічні дані, а й особисті якості. М.І. Свєнтікова акцентує увагу на тому, що «при розслідуванні злочинів, які пов'язані з незаконним ввезенням, виготовленням та збутом порнографічних предметів та вивченні особи злочинця значущими можуть виявитися будь-які людські властивості: від анатомічних та біологічних (папілярні узори, група крові тощо) до психологічних та соціальних (особливості психічних процесів, професія тощо). [11, с. 158]. 
Розглядаючи питання особи правопорушника, причетної до вчинення кримінальних правопорушень за фактами обігу порнографічних предметів слід детально розглянути співучасть декількох учасників при вчиненні даного виду кримінальних правопорушень, бо вони можуть вчинятися як одноосібно, так та декількома та більше особами за попередньою змовою.

Д.Г. Паляничко проаналізувавши особу правопорушника, яка вчинила кримінальне правопорушення проти основ суспільної моралі у сфері статевої недоторканості дітей диференціює злочинців за такими критеріями, як автори (створювачі), виготовлювачі та поширювачі порнографічних предметів [13, с. 139]. С.В. Хільченко у результаті поділу процесу (окремих актів) злочинної діяльності, пов’язаної з поширенням порнографічних предметів розрізняє: 1) виготовлювачів порнографічних предметів; 2) реалізаторів, тобто тих, котрі збувають порнографічні предмети [12, с. 40].

M.I. Свєнтіковою було досліджено питання особи правопорушника як елемента криміналістичної характеристики незаконного ввезення, виготовлення та розповсюдження порнографічних предметів та виділені такі «учасники у складі групи як організатор (лідер злочинної групи), посередники, виконавці (менеджери, виробники, імпортери чи постачальники, тиражувальники, водії, розповсюджувачі), посібники, підбурювачі, замовник» [14, с. 659].

Проаналізувавши вироки суду у кримінальних провадженнях за ст. 301 Кримінального кодексу (далі - КК) України, ухвалені у 2018 році щодо 92 осіб, нами встановлено, що з них 100\% - громадяни України; 80,4\% - чоловіки, 19,6\% - жінки; раніше засуджені - 3,3\%, не судимі - 96,7\% ; офіційно не працевлаштовані $70,7 \%$, працевлаштовані - 22,8\% , навчаються - 3,3\% ; одружені - $22,8 \%$, неодружені $-66,3 \%$, розлучені - 2,2\%, мають неповнолітніх дітей - $22,8 \%$; мають вищу освіту - 20,7\% , середню освіту - 40,2\% [15].

Отже, дослідивши погляди науковців щодо особи правопорушника в рамках методики розслідування кримінальних правопорушень за фактами обігу порнографічних предметів та проаналізувавши вироки суду за ст. 301 КК України, ми дійшли висновку, що типовий портрет правопорушника, який займається ввезенням, виготовленням, збутом та розповсюдженням порнографічних предметів являє собою особу віком від 25 до 45 років [13, с. 141], як чоловічої так і жіночої статі, що не має характерних ознак та особливостей, може вести звичайний спосіб життя, мати родину та виховувати неповнолітніх дітей. Здебільшого така особа має середню або вищу освіту, офіційно не працевлаштована та не має судимостей.

Такі фактори не виокремлюють правопорушника 3-поміж інших осіб за демографічними або індивідуальними ознаками, що ускладнює проведення досудового розслідування та пошук правопорушника, а також виявлення та профілактику вчинення кримінальних правопорушень за фактами обігу порнографічних предметів.

Висновки. Підсумовуючи викладене, важливо зазначити, що поняття особи правопорушника має значення не тільки як самостійний елемент криміналістичної характеристики, а й у взаємозв'язку з іншими елементами має важливу криміналістичну інформацію про особу, яка вчинила кримінальне правопорушення, обставини, що сприяли вчиненню кримінального правопорушення та стали підставою 
для протиправного діяння. Вивчення типового портрету правопорушника дає можливість не тільки здійснювати заходи щодо встановлення та розшуку винної особи, а й проводити діяльність щодо попередження та вчасного виявлення кримінальних правопорушень.

\section{Jimepamypa:}

1. Аверьянова Т.В., Белкин Р.С., Корухов Ю.Г., Российская Е.Р. Криминалистика : учебник для вузов / gод ред. заслуженного деятеля науки Российской Федерации, профессора Р.С. Белкина. Москва : Издательство НОРМА, 2000. 990с.

2. Криминалистика : учебник / отв. ред. Н.П. Яблоков. 3-е изд., перераб. и доп. Москва : Юристь, 2005. $781 \mathrm{c}$

3. Волобуєв А.Ф. Криміналістика. URL: http://westudents.com.ua/ knigi/424-krimnalstikavolobuv-af.html (дата звернення: 21.02.2019).

4. Советская криминалистика. Методика расследования отдельных видов преступлений / В.К. Лисиченко, В.И. Гончаренко, М.В. Салтевский, и др. под ред. В.К. Лисиченко. Киев : Выща шк. Головное изд-во, 1988. 405 с.

5. Салтевський М.В. Криміналістика (у сучасному викладі) : Підручник. Київ : Кондор, 2008. 588 с.

6. Криминалистика : учеб. для вузов / И.Ф. Герасимов, Л.Я. Драпкин, Е.П. Ищенко и др.; под ред. И.Ф. Герасимова, Л.Я. Драпкина. Москва : Высш. шк., 1994. 528 с.

7. Волобуєва 0.О. Особа, яка вчинила кримінальне правопорушення проти статевої свободи та статевої недоторканності: криміналістичний аналіз Європейські перспективи. 2015. Вип. 5. С. 111-115. URL: http://nbuv.gov.ua/UJRN/evpe_2015_5_20 (дата звернення: 21.02.2019).

8. Криминалистика : учебник / под ред. И.Ф.Пантелеева, Н.А. Селиванова. Москва : Юрид. лит., 1988. $672 \mathrm{c}$

9. Кримінальний кодекс України від 05 квітня 2001 р. №2341-III. URL: (дата звернення: 21.02.2019).

10. Тіщенко В.В. Корисливо-насильницькі злочини : криміналістичний аналіз : монографія. Одеса : Юридична література, 2002. 360 c.

11. Свєнтікова М.І. Вивчення особи виготовлювача, збувальника та розповсюджувача порнографічних предметів. Право та Безпека. 2012. № 2. C. 156-160. URL: http://nbuv.gov.ua/UJRN/ Pib_2012_2_36 (дата звернення: 21.02.2019).

12. Хільченко С.В. Методика розслідування поширення порнографічних предметів : навч. посіб. Київ : Вид. ПАЛИВОДА А.В., 2008. 152 с.

13. Паляничко Д.Г. Особа злочинця як елемент криміналістичної характеристики злочинів, пов’язаних із дитячою порнографією. Юридичний вісник. 2015. № 1. C. 138-142. URL: http://nbuv.gov.ua/ UJRN/urid_2015_1_26 (дата звернення: 21.02.2019).

14. Свєнтікова М.I. Особа злочинця як елемент криміналістичної характеристики незаконного ввезення, виготовлення та розповсюдження порнографічних предметів. Форум права. 2011. № 4 . C. 657-662. URL: http://nbuv.gov.ua/UJRN/FP_index.htm_2011_4_110 (дата звернення: 21.02.2019).

15. Єдиний державний реєстр судових рішень. URL: http://www.reyestr.court.gov.ua/Page/1 (дата звернення: 18.03.2019).

\section{Анотація}

Войчишена М. В. Криміналістична характеристика особи правопорушника через призму кримінальних правопорушень за фактами обігу порнографічних предметів. - Стаття.

Статтю присвячено дослідженню особи правопорушника як елемента криміналістичної характеристики методики розслідування кримінальних правопорушень. Визначено зміст, наукове та практичне значення даного поняття. Досліджено поняття особи правопорушника у взаємодії з іншими елементами структури криміналістичної характеристики. Розглянуто питання співучасті у вчиненні кримінального правопорушення, його значення та зміст при розслідуванні кримінальних правопорушень. Зокрема, приділено увагу узагальненню наукових досліджень особи, яка причетна до вчинення кримінальних правопорушень за фактами обігу порнографічних предметів.

Ключові слова: особа правопорушника, криміналістична характеристика, методика розслідування, кримінальне правопорушення. 


\section{Аннотация}

Войчишена М. В. Криминалистическая характеристика личности правонарушителя через призму уголовных правонарушений по фактам оборота порнографических предметов. - Статья.

Статья посвящена исследованию личности правонарушителя как элемента криминалистической характеристики методики расследования уголовных правонарушений. Определено содержание, научное и практическое значение данного понятия. Исследовано понятие личности правонарушителя во взаимодействии с другими элементами структуры криминалистической характеристики. Рассмотрены вопросы соучастия в совершении уголовного правонарушения, его значение и смысл при расследовании уголовных правонарушений. В частности, уделено внимание обобщению научных исследований лица, которое причастно к совершению уголовных правонарушений по фактам обращения порнографических предметов.

Ключевые слова: личность правонарушителя, криминалистическая характеристика, методика расследования, уголовное правонарушение.

\section{Summary}

Voichyshena M.V. Forensic characteristics of the offender through the prism of criminal offenses on the facts of the circulation of pornographic subjects. - Article.

The article is devoted to the investigation of the person of the offender as an element of forensic description of the method of investigation of criminal offenses. The content, scientific and practical significance of this concept is determined. The concept of the person of the offender in interaction with other elements of the structure of forensic characteristics, namely typical traces, situation, method, tools and means of committing a criminal offense, the person of the victim, is investigated. The question of complicity in the commission of a criminal offense, its meaning and content in the investigation of criminal offenses is considered. In particular, attention was paid to the generalization of scientific research of a person involved in the commission of criminal offenses on the facts of the circulation of pornographic subjects.

Key words: offender, forensic characteristic, investigation technique, criminal offense. 